\title{
Investigating if the Financial Markets Performance Affects the Shadow Economy: Additional Evidence From EU Countries
}

\author{
Pyrros Papadimitriou ${ }^{1}$, Thomas Poufinas ${ }^{2}$, George Galanos ${ }^{3} \&$ Charalampos Agiropoulos ${ }^{3}$ \\ ${ }^{1}$ Department of Political Science and International Relations, University of Peloponnese, Corinth, Greece \\ 2 Department of Economics, Democritus University of Thrace, Komotini, Greece \\ ${ }^{3}$ Department of International and European Studies, University of Piraeus, Piraeus, Greece \\ Correspondence: Charalampos Agiropoulos, Department of International and European Studies, University of \\ Piraeus, Piraeus, Greece.
}

Received: July 19, 2021

doi:10.5430/ijfr.v12n5p130
Accepted: August 26, 2021

Online Published: September 6, 2021

\begin{abstract}
The shadow economy also known as the informal or unobserved or underground economy, is a phenomenon that affects not only emerging markets and developing countries but also advanced economies. In general, this undeclared economic activity is hard to measure given its hidden nature in addition to its relation with unlawful activities. Nevertheless, apart from the legal aspects that may appear, shadow economy has negative implications in terms of tax revenue and social security contributions for the nations. To this end, an extensive literature has explored the measurement issues as well as the root causes of this phenomenon proving that the underground economy constitutes a significant portion of the overall economy in a number of countries. This paper tries to investigate the relationship between the shadow economy and the financial markets. This paper employs a number of panel data regression models to detect the association between the financial market metrics and the shadow economy (as a\% of GDP). The outcome of this paper is that it finds evidence that increased market capitalization, GDP per capita and FDI as well as low unemployment and inflation rates contribute to low levels of shadow economy. This can be of value to policy makers and the competent authorities of the countries that wish to find means to contain their shadow economy.
\end{abstract}

Keywords: financial markets, shadow economy, informal economy, unobserved economy, financial sector development

JEL classification: G10, G11, G20, G40

\section{Introduction}

Shadow economies have been, still are and - most likely- will be tantalizing the various countries' authorities, as well as the global institutions. The reason is simple; in some countries they can be a significant portion of their GDPs and despite the actions are taken, they continue to represent a significant amount and share of the GDP. This amount deprives from the formal economies, which in times of scarce resources can be extremely valuable and missed. The importance of shadow economy comes to the foreground especially in times of crisis, during which the authorities try to capture it so as to support the economy of the country.

According to Medina and Schneider (2018) in their IMF Working Paper, "The shadow economy includes all economic activities which are hidden from official authorities for monetary, regulatory, and institutional reasons. Monetary reasons include avoiding paying taxes and all social security contributions, regulatory reasons include avoiding governmental bureaucracy or the burden of regulatory framework, while institutional reasons include corruption law, the quality of political institutions and weak rule of law". Medina and Schneider (2018) also noted that if in some way we could capture these underground activities then the contribution to national GDP would have been extremely significant. Therefore, as stated by the authors, in their study, "...the definition of the shadow economy, tries to avoid illegal or criminal activities, do-it-yourself, or other household activities".

Financial markets are key components of the operation of the economy of a country. Consequently, it is of interest to investigate whether there is a relation amongst financial markets and the shadow economy and more specifically, whether the size of stock market in terms of market capitalization and trading activity can affect the share of shadow economy in a country. One would expect that shadow economy draws money from the market or vice versa that 
appealing financial markets would attract the attention over the lure of shadow economies.

The intuition behind our present paper lies within this precise conjecture; namely, that developed capital markets could assist in reducing the size of the underground economy. If the hypothesis above holds, it can be proved that policy makers could have a valuable steering wheel in their hands. Accordingly, we try to address this topic and identify potential relations between the financial market strength and the shadow economy. The former is measured by a series of readily available metrics, such as the market cap or the trading volume as a percent of GDP. However, we produce some additional metrics that try to capture further the market strength. The latter is primarily reflected by the shadow economy as a percent of GDP based on the definition of shadow economy as provided by Medina and Schneider (2018). At the same time, we do consider the influence of certain macroeconomic variables which reflect the strength of the entire economy of a country that have (potential) explanatory power of the phenomenon of shadow economy.

Our paper anticipates that bigger financial markets, with higher market capitalization and trading activity, have lower ratios of shadow economy for several reasons; they probably are already more mature and at the same time they belong to more developed countries; they are governed by more complete and stricter regulatory frameworks historically; they have secured the means to direct flows of money to the formal economy and not to the underground one; and, they have built the trust to continue attracting entrepreneurs and investors - the former to list their companies in these markets and the latter to invest in them.

Also, countries that exhibit higher levels of GDP (in terms of per capita, and growth), foreign direct investments (FDI) and lower levels of unemployment and inflation, are expected to experience smaller shadow economies, as they can provide sufficient income compared to the expense of living for their citizens; they probably have already inspired confidence to foreign investors who entrust their capital to these countries; they have stronger law enforcement historically and their citizens are more willing to comply as their standard of living does not drive them towards underground transactions.

Our paper finds evidence that the majority of our expectations hold true, i.e. that stronger capital markets imply a smaller shadow economy. As stated, this can assist the policymakers to find ways to corner the informal activities. To our knowledge, this approach has not been researched in the past and there lies our contribution in the field. The novelties of our paper are thus summarized as follows: (i) introducing market related variables; (ii) combining them with economy related variables; (iii) employing a series of econometric methods; and (iv) applying them to a wide range of countries (the $28 \mathrm{EU}$ countries) over an extended period of time ( 25 years).

\section{Literature Review}

\subsection{Shadow Economy and Financial Sector}

Activities falling under the field of shadow economy can be observed in various forms and practices. We can meet with the term shadow economy in literature as an underground activity, hidden sector, etc. (Beloded, 2005). One of the most used and versatile definitions for this type of economic activity stated by Schneider and Enste (2000) is that "shadow economy includes all economic activities which contribute to the officially calculated (or observed) Gross National Product, but are currently unregistered".

Usually, it takes a combination of reasons and foreseen advantages for businesses to turn to shadow economy practices, and rarely, if ever a unique one. This combination depends on the country, the local or national culture, even the sector that each business belongs. However, the most frequent reasons for firms and individuals to turn to underground economy are the higher tax rates and social security contributions, the increased regulation, the forced reduction of weekly working hours, the earlier retirement, the unemployment and the decline of civic virtue and loyalty towards public institutions (Park, 2005). Although the implications of such activities are multifold, in the long run the growth of underground economy gradually weakens economic and the social basis of collective arrangements.

In a recent research in Malaysia (Din, 2016) the developed long-run models, suggested that tax burden and unemployment rates, strongly increase the size of the shadow economy, with the relationship between shadow economy and financial sector development (measured by ratio of domestic credit to private sector to GDP) to exhibit an inverted U-shape curve. This kind of relationship indicates that shadow economy increases at lower levels of financial development, but since financial development is enhanced, shadow economy tends to demonstrate decreasing trends. A similar study was performed by Habibullah (2016) for Malaysia, with Din as one of the coauthors, producing similar results. These conclusions are in the same approach as those expressed by other researchers like Bose et al. (2012), Blackburn et al. (2012), Bittencourt et al. (2014), and Berdiev \& Saunoris (2016) who used different measures of financial development (banking development, higher costs of financial intermediation, costly state verification, and (1) money and quasi money (M2), (2) domestic credit provided by financial corporations to the private sector and (3) 
domestic credit from the financial sector including gross credit to various sectors and net credit to the central government - all three as a percent of GDP, respectively for the four papers).

Capasso \& Jappelli (2013) developed a model which concluded that financial development, in terms of a reduction in the cost of external finance, can reduce tax evasion and the size of the underground economy. They tested the main implications of their model using microeconomic data from Italy which allowed them to create a micro-based index of the underground economy. In line with the model's predictions, they found out that local financial development is associated with a smaller size of the shadow economy.

A totally difficult exercise in this field, is to estimate the size of the informal economy. It is reasonable that all businesses and individuals involved are trying to avoid detection, and as a result many states, have great difficulties in their attempts to monitor underground activity. It is impossible to have a total direct measure of the size and composition of shadow economy, at least until today, however, academics and political community have made out a number of different estimation methods for achieving acceptable approximations (Anoop, 2012). Three groups of methods are widely used; sampling direct approaches, indirect approaches and model approaches. Each type of methods has its own pros and cons, and we must keep in mind that the resulting estimated result can strongly vary (Park, 2005).

Strongly related with shadow economy, recent cases of improper governance provided attention on the need for inclusive growth and strong institutions. This is particularly true for developing countries, where it is usual the big size of their informal economies to limit official authorities' capacity to deliver governance and strong institutions. These seem to have strong influence in discouraging the participation in and expansion of the formal economy. IMF analysed the determinants of the underground economy, putting strong emphasis on the impact of presences or absence of institutions and rule of law (Singh et al, 2012a; 2012b). They discovered that when businesses are operating under arduous regulation, inconsistent enforcement and large corruption, they tend to hide their activities, and thus becoming much more active in the underground economy. In addition, based on empirical analysis they concluded that institutions are the most important determinant, regarding the size of shadow economy. Obviously the level of tax rates was also a strongly influential determinant but not as this of proper institutions. To this end, a strong policy incentive is arising, since large reductions in taxes will not support the fight against shadow economy. Similar outcome accounts when increasing the number and complexity of regulations. National economies will enjoy much better results, by strengthening the rule of law, simplifying access to formal economy, and applying strict enforcement of a limited and simple set of regulations framework (Singh et al, 2012a; 2012b). In a more recent IMF (Working Paper) variant, Kelmanson et al (2019) examine the drivers and re-estimate the size of shadow economies in Europe, focusing on the emerging economies finding that the size of shadow economies declined across Europe in recent years but still remains significant especially in Eastern Europe. The key determinants of the size of the shadow economy are the regulatory quality, the government effectiveness and the human capital. The authors recommend policies to increase formality, such as reducing regulatory and administrative burden, promoting transparency, improving government effectiveness, increasing tax compliance, automating procedures and promoting electronic payments. Their findings and recommendations are in line with the earlier findings and recommendations of Singh et al (2012a;2012b).

A complementary approach is the one followed by Hajilee et al (2017) who view financial market development under the prism of financial inclusion. They therefore examine the impact of the shadow economy on financial market inclusion in the short run and in the long run for 18 emerging economies to find that the shadow economy has significant short-run asymmetric effects on the financial market inclusion of a majority of emerging economies in their sample.

\subsection{The Impact of Banking Development on the Size of Shadow Economies}

Bose, Capasso and Wurm, (2012), demonstrated the level of financial/ banking development as new key factor in the shadow economies. In order to prove the importance of this factor and since shadow economies are difficult to measure, they used two different sources of measurement. The first source is Schneider's estimation approach using DYMIMIC (Schneider, 2007). The second source is the use of surveys on the shadow economies, by the World Economic Forum Data. Their hypothesis suggested that the availability of credit and the terms of borrowing affect the size of the shadow economies. Thus, they focused on various banking indicators that reflect both the depth and the efficiency of the banking sector. These included liquidated liabilities and total domestic credit provided by depository banks, both as a percentage of GDP. Their findings showed that both indices had a significant impact on reducing the size of the shadow economies. For even more insight, they repeated the baseline regression line including a broader list of Banking efficiency Indicators (Central Bank Assets - Interest Rate Spread - Net Interest Margin - Bank Concentration - Bank Overheads - Banks Capital) and they have showed that in the case of the four of the six indicators above, the influence 
was significant, implying that the effectiveness of the banking sector plays an important role in reducing the size of the shadow economies.

Although much of the existing literature focuses on the burden of taxation or the regulatory framework, the quality of government, law enforcement, corruption, etc, when determining the factors of the shadow economies, Bose, Capasso and Wurm (2012) showed that improving the development of the banking / credit sector is linked to smaller shadow economies. The data presented in their paper suggested another channel through, which the development of the banking sector could affect real activity, concluded its impact on the size of the shadow economies.

Fetai (2018) developed an empirical econometric model for evaluating the relationship and causal link between financial development, the financial crisis, and the real GDP per capita growth, in European countries in transition, including Russian Federation and Turkey. Fetai used Financial Data from 20 countries from 1998 to 2015 sourced from the World Bank, the IMF and the EBRD. His study used the Hausman-Taylor model, which is more consistent and effective. The results of the model have shown that Financial Development (FDI - Market Capitalization plus Domestic Credit to Private Sector as per cent of the GDP) and Liquid Liabilities (LLB- Liquid Liabilities as per cent of the GDP) have a positive effect on the increase in Real GDP per capita (yit). In addition, the model supports the assumption that financial development generates economic growth (and not just following the economic growth). The results also showed that crisis has a negative effect on the real GDP per capita growth. General government consumption and inflation also have a negative impact on real GDP per capita growth. Moreover, Fetai's model, concludes that higher government spending may undermine economic growth by reallocation of the resource from private productive activities to the government, which uses them inefficiently.

The results of Fetai's study may serve as a basis for proposing a course of actions for central banks in transition economies, including institutional improvement and encouraging competition in the financial sector. Future research in this area will extend the sample to developing countries and include foreign assets and liabilities as percentage of GDP, i.e. financial integration, and examine the relationship and causal link between financial integration and economic growth.

As seen above, an extensive literature has explored the measurement issues as well as the root causes of shadow economy's negative implications in terms of tax revenue and social security contributions for the nations, proving that the underground economy constitutes a significant portion of the overall economy in a number of countries. Our paper will try to investigate the relationship between the shadow economy and the financial markets, employing a number of panel data regression models.

\section{Quantitative Approach}

\subsection{Data, Variables and Methodology}

\subsubsection{Data}

Our dataset consists of the twenty-eight countries of the European Union. These are Austria, Belgium, Bulgaria, Croatia, Cyprus, Czech Republic, Denmark, Estonia, Finland, France, Germany, Greece, Hungary, Ireland, Italy, Latvia, Lithuania, Luxembourg, Malta, Netherlands, Poland, Portugal, Romania, Slovak Republic, Slovenia, Spain, Sweden and the United Kingdom. The relevant figures are for the period 1991 - 2015, as this is the period incorporating the crisis and data were available. Our data for shadow economy come from Schneider and The World Bank for the long term interest rate, the market capitalization of listed domestic companies (\% of GDP), the market capitalization of listed domestic companies (log of current US\$), the S\&P Global Equity Indices (annual\% change), the stocks traded total value (\% of GDP), the stocks traded - total value (log of current US\$), the stocks traded - turnover ratio of domestic shares (\%), the foreign direct investment (FDI) - net inflows (BoP, log of current US\$), the GDP growth (annual\%), GDP per capita (current in thousand US\$), the inflation - consumer prices (annual\%) and the unemployment - total (\% of total labor force - national estimate).

\subsubsection{Variables}

The variables that are used as the financial market metrics (independent variables) are the long term interest rate, the market capitalization of listed domestic companies (\% of GDP), the market capitalization of listed domestic companies (log of current US\$), the S\&P Global Equity Indices (annual\% change), the stocks traded - total value (\% of GDP), the stocks traded - total value (log of current US\$), the stocks traded - turnover ratio of domestic shares (\%). We use the foreign direct investment - net inflows (BoP, log of current US\$), the GDP growth (annual\%), the GDP per capita (current in thousand US\$), the inflation - consumer prices (annual\%) and the unemployment - total (\% of total labor force - national estimate) as control variables. The variable that is used as the shadow economy parameter (the dependent variable) is the shadow economy as a percent of GDP per country. 
Table 1. Summary statistics

\begin{tabular}{|c|c|c|c|c|c|c|c|c|c|c|c|c|c|}
\hline & SE & MC & LMC & S\&P & ST & LST & STT & UN & FDI & GDP & GDPpc & INF & IR \\
\hline mean & 20,260 & 49,730 & 24,860 & 8,213 & 23,370 & 23,050 & 50,310 & 9,104 & 22,170 & 2,510 & 24,950 & 13,200 & 4,893 \\
\hline p50 & 20,580 & 37,810 & 24,980 & 7,675 & 8,373 & 23,440 & 35,660 & 8,024 & 22,260 & 2,647 & 21,770 & 2,406 & 4,545 \\
\hline sd & 7,594 & 42,240 & 2,275 & 32,570 & 34,400 & 3,347 & 58,300 & 4,442 & 1,993 & 3,509 & 19,210 & 82,020 & 3,048 \\
\hline variance & 57,680 & 1784 & 5,177 & 1061 & 1184 & 11,200 & 3398 & 19,730 & 3,972 & 12,310 & 369,100 & 6727 & 9,289 \\
\hline $\mathrm{N}$ & 700 & 519 & 520 & 645 & 579 & 581 & 497 & 552 & 707 & 764 & 770 & 777 & 624 \\
\hline range & 29,640 & 326,300 & 13,440 & 262,200 & 266,000 & 19,160 & 694,400 & 25,980 & 12,810 & 39,930 & 117,700 & 1504 & 24,040 \\
\hline $\min$ & 7,690 & 0,046 & 15,540 & $-73,020$ & 0,000 & 9,903 & 0,050 & 1,482 & 14,510 & $-14,810$ & 1,102 & $-4,478$ & 0,090 \\
\hline $\max$ & 37,330 & 326,400 & 28,980 & 189,200 & 266,000 & 29,060 & 694,400 & 27,470 & 27,320 & 25,120 & 118,800 & 1500 & 24,130 \\
\hline
\end{tabular}

Notes: SE: Shadow Economy (\%), MC: Market capitalization of listed domestic companies (\% of GDP), LMC: Market capitalization of listed domestic companies (Log - current US\$), S\&P: S\&P Global Equity Indices (annual\% change), ST: Stocks traded, total value (\% of GDP), LST: Stocks traded, total value (Log - current US\$), STT: Stocks traded, turnover ratio of domestic shares (\%), UN: Unemployment, total (\% of total labor force), FDI: Foreign direct investment, net inflows (BoP, Log - current US\$), GDPpc: GDP per capita (current kUS\$), INF: Inflation, consumer prices (annual\%), IR: Long Term Interest Rate (\%)

Table 1 shows some descriptive statistics of the data covering the full-sample period. It provides the means, medians, standard deviations, variance, minimum and maximum values for the different cross sections. It can be seen that the data set is characterized by considerable variations within/between cross sections. In particular, the financial market measures S\&P (S\&P Global Equity Indices (annual\% change)) and ST (Stocks traded, total value (\% of GDP)) appear to have great difference between mean and median which implies that data is seriously skewed, and in this case the median becomes far more representative.

\subsubsection{Methodology}

We regressed the shadow economy as a percent of GDP per country (dependent variable) with the aforementioned financial markets metrics and macroeconomic variables to identify the potential impact of financial markets on shadow economy and find potential evidence of whether the tendency of the markets could possible affect the percentage of the shadow economy in a country.

Table 2. Correlation matrix

\begin{tabular}{|c|c|c|c|c|c|c|c|c|c|c|c|c|c|}
\hline & SE & MC & LMC & S\&P & ST & LST & STT & UN & FDI & GDP & GDPpc & INF & IR \\
\hline SE & 1 & & & & & & & & & & & & \\
\hline MC & $-0,441$ & 1 & & & & & & & & & & & \\
\hline LMC & $-0,555$ & 0,545 & 1 & & & & & & & & & & \\
\hline S\&P & 0,024 & 0,154 & 0,062 & 1 & & & & & & & & & \\
\hline ST & $-0,300$ & 0,493 & 0,627 & $-0,048$ & 1 & & & & & & & & \\
\hline LST & $-0,499$ & 0,319 & 0,906 & 0,007 & 0,685 & 1 & & & & & & & \\
\hline STT & $-0,153$ & 0,066 & 0,407 & $-0,166$ & 0,652 & 0,594 & 1 & & & & & & \\
\hline UN & 0,279 & $-0,319$ & $-0,123$ & 0,016 & $-0,081$ & $-0,023$ & 0,010 & 1 & & & & & \\
\hline FDI & $-0,593$ & 0,517 & 0,728 & $-0,044$ & 0,525 & 0,689 & 0,338 & $-0,192$ & 1 & & & & \\
\hline GDP & $-0,032$ & 0,118 & $-0,092$ & 0,153 & $-0,013$ & $-0,127$ & $-0,110$ & $-0,138$ & $-0,024$ & 1 & & & \\
\hline GDPpc & $-0,654$ & 0,564 & 0,432 & $-0,080$ & 0,160 & 0,235 & 0,028 & $-0,327$ & 0,550 & $-0,085$ & 1 & & \\
\hline INF & 0,204 & $-0,226$ & $-0,458$ & $-0,105$ & $-0,064$ & $-0,155$ & $-0,034$ & 0,043 & $-0,243$ & $-0,158$ & $-0,164$ & 1 & \\
\hline IR & 0,386 & $-0,215$ & $-0,199$ & 0,026 & $-0,138$ & $-0,033$ & $-0,067$ & 0,255 & $-0,273$ & $-0,203$ & $-0,390$ & 0,535 & 1 \\
\hline
\end{tabular}

Notes: SE: Shadow Economy (\%), MC: Market capitalization of listed domestic companies (\% of GDP), LMC: Market capitalization of listed domestic companies (Log - current US\$), S\&P: S\&P Global Equity Indices (annual\% change), ST: Stocks traded, total value (\% of GDP), LST: Stocks traded, total value (Log - current US\$), STT: Stocks traded, turnover ratio of domestic shares (\%), UN: Unemployment, total (\% of total labor force), FDI: Foreign direct investment, net inflows (BoP, Log - current US\$), GDPpc: GDP per capita (current kUS\$), INF: Inflation, consumer prices (annual\%), IR: Long Term Interest Rate (\%). 
Table 2 presents the correlation matrix among all variables used in our models. It can be seen that most of the financial measures are seriously correlated with the shadow economy. In particular, Market capitalization of listed domestic companies and Stocks Traded (both as percent of GDP and log of current US\$), appear to negatively correlated with shadow economy (-0.441/-0.555 and -0.300/-0.499 respectively). In contrast, the variable S\&P Global Equity Indices (annual\% change) is positively correlated (0.024) with shadow economy regardless of the country and time level. As for the macroeconomic variables, Table 2 reveals that unemployment rate, inflation and long-term interest rate are positively correlated with shadow economy, with a correlation coefficient of $0.279,0.204$ and 0.386 respectively whereas FDI and GDP per capita are negatively correlated with shadow economy (with a correlation coefficient of -0.593 and -0.654 respectively).

To the best of our knowledge this study contributes to the existing literature by adopting for the first time in the empirical literature a fixed effects and a random effects model to properly account for the imposition of possible effects on shadow economy. We supplement our analysis by using parametric techniques (GMM estimators) in order to compare and contrast our findings.

Before proceeding to unit root and cointegration tests we test for cross-section dependence. We use the cross-section dependence test (CD test) proposed by Pesaran (2004). CD test strongly rejects the null hypothesis of cross-section independence for all the sample variables. In face of this evidence, we proceed to test for unit roots using the so-called "second generation" tests for unit roots in panel data that are robust to cross-section dependence (see Pesaran, 2015). To examine the stationarity properties of the variables in our models we use the second-generation panel unit root tests developed by Maddala and Wu (1999) and Pesaran (2003) both suitable for unbalanced panel data set and cross-section dependence. The null hypothesis of a unit root (non-stationarity) cannot be rejected for all the sample variables. This means that the variables contain a unit root (e.g., integrated of order one) as expected by the visual inspection of their time series. In order to investigate whether a long-run equilibrium relationship exists among the sample variables we implement Pedroni's (1999] ADF-based and PP-based cointegration tests as well as Kao's (1999) ADF-based tests. Both tests suggest the rejection of the null hypothesis of no cointegration null at any significance level.

\subsubsection{Fixed Effects Model}

The fixed effects model is simply a linear regression model in which the intercept terms vary over the individual units $i$, i.e.

$$
y_{i t}=a_{i}+x_{i t}^{\prime} \beta+\varepsilon_{i t}, \varepsilon_{i t} \sim I I D\left(0, \sigma_{\varepsilon}^{2}\right)
$$

where it is usually assumed that all $x_{i t}$ are independent of all $\varepsilon_{i t}$. We can write this in the usual regression framework by including a dummy variable for each unit $i$ in the model (Verbeek, 2008). That is,

$$
y_{i t}=\sum_{j=1}^{N} a_{j} d_{i j} x_{i t}^{\prime} \beta+\varepsilon_{i t}
$$

where $d_{i j}=0$ when $i=j$ and 0 elsewhere. We have also assumed the strictly exogenous regressors case in the conditional moments (see Woolridge, 2009). We have not assumed equal sized groups in the panel. The vector $\beta$ is a set of parameters of primary interest, $\alpha_{i}$ is the group specific heterogeneity. We have included time specific effects but, they are only tangential in what follows. Since the number of periods is usually fairly small, these can usually be accommodated simply by adding a set of time specific dummy variables to the model. Our interest here is in the case in which $N$ is too large to do likewise for the group effects.

\subsubsection{Random Effects Model}

It is commonly assumed in regression analysis (Verbeek, 2008) that all factors that affect the dependent variable, but that have not been included as regressors, can be appropriately summarized by a random error term. In our case, this leads to the assumption that the $\alpha_{i}$ are random factors, independently and identically distributed over individuals. Thus we write the random effects model as:

$$
y_{i t}=\mu+a_{i}+x_{i t}^{\prime} \beta+\varepsilon_{i t}, \varepsilon_{i t} \sim I I D\left(0, \sigma_{\varepsilon}^{2}\right) ; \alpha_{i} \sim I I D\left(0, \sigma_{\alpha}^{2}\right)
$$

where $a_{i}+\varepsilon_{i t}$ is treated as an error term consisting of two components: an individual specific component, which does not vary over time, and a remainder component, which is assumed to be uncorrelated over time. It is also assumed that $a_{i}$ and $\varepsilon_{i t}$ are mutually independent and independent of $x_{j s}$ (for all $\mathrm{j}$ and $\mathrm{s}$ ).

\subsubsection{Arellano \& Bond - GMM}

With the intention to examine the dynamic aspects we use dynamic panel data techniques such as Difference Generalized Method of Moments (DIF-GMM) estimators attributed to Arellano and Bond (1991) and System Generalized Method of Moments (SYS-GMM) estimators proposed by Blundell and Bond (1998) respectively. The 
use of the latter is mainly justified as it improves significantly the estimates' accuracy and enlarges efficiency when the lagged dependent variables are considered as poor instruments as in the first-differenced regressors (Greene, 2003, Baltagi, 2002). As a consequence, the SYS-GMM gives more robust results than the first-differenced GLS and GMM estimation methods (Bond et al., 2001).

The GMM estimators rely on moments of the form:

$$
h(\beta)=\sum_{i=1}^{N} h_{i}(\beta)=\sum_{i=1}^{N} \Psi_{i}^{\prime} u_{i}^{\prime}(\beta)
$$

where $\Psi_{i}$ is a $T_{i} \times p$ matrix of instruments for cross section $i$ and $u_{i}(\beta)=\left(Y_{i}-f\left(X_{i t}, \beta\right)\right)$. Specifically, GMM minimizes the following quadratic form with respect to $\beta$

$$
M(\beta)=\left(\sum_{i=1}^{N} \Psi_{i}^{\prime} u_{i}(\beta)\right)^{\prime} W\left(\sum_{i=1}^{N} \Psi_{i}^{\prime} u_{i}(\beta)\right)=\zeta^{\prime}(\beta) W \zeta(\beta)
$$

Where $W$ is a $\operatorname{pxp}$ weighting matrix.

The coefficient covariance matrix is estimated as:

Where $\Xi$ is estimated as:

$$
V(\hat{\beta})=\left(G^{\prime} W G\right)^{-1}\left(G^{\prime} W \Xi W G\right)\left(G^{\prime} W G\right)^{-1}
$$

And $G$ is a $T_{i} \times k$ matrix given as:

$$
E\left(\zeta_{i}(\beta) \zeta_{i}(\beta)^{\prime}\right)=E\left(\Psi_{i}^{\prime} u_{i}(\beta) u_{i}(\beta)^{\prime} \Psi_{i}\right)
$$

$$
G(\beta)=\left(-\sum_{i=1}^{N} \Psi_{i}^{\prime} \nabla f_{i}(\beta)\right)
$$

The weighting of matrix $W$ can be calculated using the White robust covariances, which are given as:

$$
\left(\frac{M^{*}}{M^{*}-k^{*}}\right)\left(\sum_{t} X_{t}^{\prime} X_{t}\right)^{-1}\left(\sum_{t} X_{t}^{\prime} \hat{u}_{t} \hat{u}_{t}^{\prime} X_{t}\right)\left(\sum_{t} X_{t}^{\prime} X_{t}\right)^{-1}
$$

The first parenthesis is an adjustment to the degrees of freedom relying on the total number of observations; $M^{*}$ is the total number of stacked observations and $k^{*}$ the number of estimated parameters. The general form of the equation estimated with panel data dynamic models is one with individual effects like the following:

$$
Y_{i t}=\lambda_{t}+\eta_{i}+\sum_{k=1}^{p} \alpha_{k} Y_{i(t-k)}+\beta^{\prime}(L) X_{i t}+v_{i t}
$$

for $i=1,2, \ldots, T$, where $\lambda_{t}$ and $\eta_{i}$ correspond to specific and individual effects, $X_{i t}$ is a vector of explanatory variables, $\beta(L)$ is a vector of associated polynomials in the lag operator and $\mathrm{q}$ is the maximum lag length. Identification of the model requires restrictions on the serial correlation of the error term $v_{i t}$ and on the properties of the independent variables $X_{i t}$ allowing only for MA or white noise errors. If the error term was originally autoregressive, the model is transformed.

Orthogonal deviations as proposed by Arellano and Bond (1988) express each observation as the deviation from the average of future observations in the sample and weight each deviation to standardize the variance:

$$
x_{i t}^{*}=\left[x_{i t}-\left(x_{i(t+1)}+\ldots+x_{i T}\right) /(T-t)\right] \sqrt{(T-t)} / \sqrt{T-t+1}
$$

for $t=1,2, \ldots, T-1$.

The $T_{i}-q$ equations for individual unit $i$ can be written as:

$$
Y_{i}=\delta w_{i}+d_{i} \eta_{i}+v_{i}
$$

where $\delta$ is a parameter vector including $\alpha_{\kappa}, \beta$ and $\lambda$; and $w_{i}$ is a data matrix containing the time series of the lagged endogenous variables, the $x^{\prime} \mathrm{s}$, and the time dummies. The $d_{i}$ is a $\left(T_{i}-q\right) \times 1$ vector of ones. Following Arellano and Bond (1998), linear GMM estimators of $\delta$ may be computed by the following expression:

$$
\hat{\delta}=\left[\left(\sum_{i} w_{i}^{* \prime} Z_{i}\right) \cdot \frac{1}{\frac{1}{N} \sum_{i} Z_{i}^{\prime} H_{i} Z_{i}} \cdot\left(\sum Z_{i}^{\prime} w_{i}^{*}\right)\right]^{-1} \cdot\left(\sum_{i} w_{i}^{* \prime} Z_{i}\right) \frac{1}{\frac{1}{N} \Sigma_{i} Z_{i}^{\prime} H_{i} Z_{i}}\left(\sum_{i} Z_{i}^{\prime} Y_{t}^{*}\right)
$$

where $w_{i}^{*}$ and $Y_{i}^{*}$ denote some transformation of $w_{i}$ and $Y_{i}$ such as first differences, orthogonal deviations or levels. $Z_{i}$ is the matrix of instrumental variables and $H_{i}$ is an individual specific weighting matrix. We may have one-step estimates, which use some known matrix as the choice for $H_{i}$. For a first - difference procedure, the one-step estimator uses $H_{i}$, while for orthogonal deviations or for a levels procedure the one-step estimator sets $H_{i}$ to an identity matrix. If the $v_{i t}$ are heteroskedastic, a two-step estimator is used. 


\subsection{Regression Summary}

The particulars of the regressions we ran appear in the following tables 3 for the shadow economy dependent variable. The output of all three models, i.e., fixed and random effects and Arellano - Bond estimators are shown per independent variable for comparison purposes also.

In Table 3 for each of the independent variables the first row indicates the coefficients, whereas the second row, where the numbers are put in the parentheses, indicates the standard error of the estimators.

Table 3. Regression results

\begin{tabular}{|c|c|c|c|}
\hline & Fixed Effects & Random Effects & Arellano-Bond \\
\hline & b/se & b/se & b/se \\
\hline \multirow[t]{2}{*}{ MC } & 0.001 & -0.002 & $-0.010^{* * *}$ \\
\hline & $(0.01)$ & $(0.00)$ & $(0.00)$ \\
\hline \multirow[t]{2}{*}{ LMC } & $-1.637 * * *$ & $-1.443^{* * * *}$ & $-0.939 * * *$ \\
\hline & $(0.36)$ & $(0.29)$ & $(0.19)$ \\
\hline \multirow[t]{2}{*}{$\mathrm{S} \& \mathrm{P}$} & $0.020 * * *$ & $0.019 * * *$ & $0.022 * * *$ \\
\hline & $(0.00)$ & $(0.00)$ & $(0.00)$ \\
\hline \multirow[t]{2}{*}{ ST } & $0.014^{*}$ & $0.013^{*}$ & $0.012 * *$ \\
\hline & $(0.01)$ & $(0.01)$ & $(0.01)$ \\
\hline \multirow[t]{2}{*}{ LST } & -0.243 & -0.202 & $-0.382 * * *$ \\
\hline & $(0.19)$ & $(0.19)$ & $(0.13)$ \\
\hline \multirow[t]{2}{*}{ STT } & 0.003 & 0.003 & $0.009^{* *}$ \\
\hline & $(0.00)$ & $(0.00)$ & $(0.00)$ \\
\hline \multirow[t]{2}{*}{ UN } & $0.103 *$ & $0.111^{*}$ & $0.183^{* * * *}$ \\
\hline & $(0.06)$ & $(0.06)$ & $(0.02)$ \\
\hline \multirow[t]{2}{*}{ FDI } & $-0.177 * *$ & $-0.168 * *$ & -0.103 \\
\hline & $(0.07)$ & $(0.07)$ & $(0.06)$ \\
\hline \multirow[t]{2}{*}{ GDP } & -0.024 & -0.029 & -0.023 \\
\hline & $(0.03)$ & $(0.02)$ & $(0.02)$ \\
\hline \multirow[t]{2}{*}{ GDPpc } & $-0.042 * *$ & $-0.054 * * *$ & $-0.112 * * *$ \\
\hline & $(0.02)$ & $(0.01)$ & $(0.01)$ \\
\hline \multirow[t]{2}{*}{ INF } & $0.144^{*}$ & $0.146^{*}$ & $0.267 * * *$ \\
\hline & $(0.07)$ & $(0.08)$ & $(0.04)$ \\
\hline \multirow[t]{2}{*}{ IR } & 0.022 & 0.025 & -0.044 \\
\hline & $(0.06)$ & $(0.06)$ & $(0.03)$ \\
\hline \multirow[t]{2}{*}{ constant } & $68.351 * * *$ & $63.127 * * *$ & $53.983^{* * *}$ \\
\hline & $(10.20)$ & $(8.62)$ & $(2.64)$ \\
\hline $\mathrm{R}$-sqr & 0.664 & & \\
\hline dfres & 22 & & \\
\hline BIC & 708.0 & . & . \\
\hline \multicolumn{4}{|c|}{$* \mathrm{p}<0.10, * * \mathrm{p}<0.05, * * * \mathrm{p}<0.01$} \\
\hline \multicolumn{4}{|c|}{$\begin{array}{l}\text { Notes: SE: Shadow Economy (\%), MC: Market capitalization of listed domestic companies (\% of GDP), LMC: Market } \\
\text { capitalization of listed domestic companies (Log - current US\$), S\&P: S\&P Global Equity Indices (annual\% change), } \\
\text { ST: Stocks traded, total value (\% of GDP), LST: Stocks traded, total value (Log - current US\$), STT: Stocks traded, } \\
\text { turnover ratio of domestic shares (\%), UN: Unemployment, total (\% of total labor force), FDI: Foreign direct } \\
\text { investment, net inflows (BoP, Log - current US\$), GDPpc: GDP per capita (current kUS\$), INF: Inflation, consumer } \\
\text { prices (annual\%), IR: Long Term Interest Rate }(\%) \text {. }\end{array}$} \\
\hline
\end{tabular}

\subsection{Results and Implications}

\subsubsection{Results}

From the regressions run, we realize that the market capitalization of listed domestic companies (\% of GDP) and the stocks traded - total value (log of current US\$ are negatively correlated with the shadow economy as a percent of GDP and statistically significant at all levels, when the Arellano-Bond approach is used. We see that the market capitalization of listed domestic companies (log of current US\$) is also negatively correlated with the shadow economy and statistically significant at all levels for all three models, i.e. fixed effects, random effects and Arellano-Bond.

The S\&P Global Equity Indices (annual\% change) is positively correlated with the shadow economy as a percent of GDP and statistically significant at all levels also for all three approaches (fixed effects, random effects and Arellano-Bond). The stocks traded - total value (\% of GDP) is positively correlated with the shadow economy at the 
$5 \%$ level, when the Arellano-Bond approach is used and at the $10 \%$ level, when the fixed and random effects models are used. The stocks traded - turnover ratio of domestic shares (\%) is positively correlated with the shadow economy at the 5\% level, when the Arellano-Bond model is used.

When it comes to the control variables we realize that the inflation - consumer prices (annual\%) and the unemployment - total (\% of total labor force - national estimate) are positively correlated at all significance levels with the shadow economy for the Arellano-Bond model; the same holds true at the fixed effects and random effects models but at the $10 \%$ significance level. The GDP per capita (current in thousand US\$) is negatively correlated at all significance levels with the shadow economy at all significance levels with the Arellano-Bond method; the same holds true for the fixed effects and random effects at the 5\% and $1 \%$ level respectively. The foreign direct investment - net inflows (BoP, log of current US\$) is negatively correlated at the 5\% level with the shadow economy when the fixed effects and random effects models are employed.

The constant term is statistically significant at all levels with all three methods. For the remaining of the variables there seems to be no statistical significance; however, they were incorporated in the model as they contribute to the goodness of fit.

\subsubsection{Interpretation and Implications}

The regressions ran indicate that when the market cap (both as a percent of GDP and in absolute amount (log)) are tested there is a negative correlation with the shadow economy; the same applies when the value of stocks traded (log of absolute amount) is considered. This finding is probably anticipated as countries that have low market cap leave space for higher underground economy and vice versa, countries with high market cap do not foster underground economy. There could be many reasons for that; however, we expect that countries with high market cap (both as a percent of GDP and as an absolute amount) are mature and developed, have managed to gain the trust of the investors, exactly because they have the infrastructure and the regulatory framework to minimize grey economy. The value of stocks traded as an absolute amount also subscribes to this point of view, potentially in line with the market cap. Another interpretation is that the higher the shadow economy, the weaker the market is, as underground activity draws a big portion of the money that could have been otherwise invested to the financial markets.

However, when the market performance as measured by the S\&P Global Equity Indices and the trading activity as mapped by the stocks traded - total value (\% of GDP) and the stocks traded - turnover ratio of domestic shares (\%) are investigated, then we see that they are positively correlated with the shadow economy. A potential interpretation could be that, in countries that exhibit higher (perceived) underground activity, both enterprises and individual investors do not properly declare earnings and direct undeclared income to the stock market. The high performance could further attract investors. This impacts the performance positively and results in higher trading activity. Especially with regards to the performance, one needs to consider the potential impact of the local currency, as the S\&P indices are measured in USD terms. Consequently, local currency appreciation versus the USD could lead to higher performance. In addition, shadow economy could foster higher trading activity compared to the GDP and not in absolute amounts as well as higher turnover, as a means to direct money into the formal economy. This is a finding though that needs to be further examined.

When we look at the control variables, we observe that inflation and unemployment move at the same direction with the shadow economy. This means that high inflation and high unemployment rates imply high shadow economy, a finding that is probably anticipated, as high inflation and high unemployment levels give room for undeclared activity, such as undeclared transactions or undeclared employment. The former is in line with the findings of Bittencourt et al. (2014). At the same time high levels of GDP per capita and FDI yield low levels of shadow economy, which can be possibly explained by the fact that in countries that are more prosperous and thus more developed and mature, citizens perform (the majority of) their transactions within the formal economy, whereas in countries with lower income levels the citizens rely also for (a bigger portion of) their transactions on the grey economy, so as to make their living. At the same time countries that attract FDI again contain their levels of shadow economy, as they have built the fiscal and regulatory framework abolish it. It is also possible that their citizens do not desire it or even do not need it as much as they do in countries with lower FDI. Alternatively, it could mean that the individuals or enterprises that pursue the FDI continue to invest in countries with (perceived) decreased shadow economy.

The aforementioned findings provide some evidence that the competent authorities may have several tools at hand to contain the unobserved economy. Namely, they can further develop their capital markets in terms of market capitalization, both as a percent of GDP, as well as in absolute dollar terms. These two possibly go together. Market capitalization can increase either by increasing the number of listed firms or by the listing of bigger companies. In both cases, this is an indication of trust on behalf of the entrepreneurs as well as the investors. This is anticipated to further reduce the impact of the shadow economy. 
In addition, our control variables indicate that countries need to fight inflation and unemployment to further reduce shadow economy. This is probably more difficult to achieve; however, it helps in securing that employment is declared and that the remuneration levels suffice for a good level of living. At the same time, establishing higher levels of GDP per capita contributes to the same direction, as individuals will not need to rely that much on undeclared transactions, but will rather choose to perform their activities through the formal channels. Furthermore, increasing the FDI seems to strengthen the effort towards the further shrinking of the shadow economy.

Impacting the unemployment, the inflation, the GDP per capita and the FDI may be a challenging target. Steering though the capital markets in the correct direction is more focused and more feasible. The common European regulation definitely helps in this direction. Consequently, policy makers can find value in the aforementioned findings as evidence is provided that there are ways to contain shadow economy.

\section{Conclusion and Further Research}

We found evidence that the capital market as measured by the market capitalization (as a percent of GDP and in absolute amounts $(\log )$ ) seems to be an important determinant for limiting the size of the shadow economy. The same holds true for the trading activity as an amount. Furthermore, the level of GDP (per capita and growth), the FDI, the unemployment and the inflation rate are also determinants of the level of shadow economy. When the first two increase and the last two decrease, the shadow economy seems to be shrinking. We still need to further investigate the relation of the performance of the stock markets, as well as the relevant size of the trading activity with the shadow economy as they produce results in the opposite direction, which although we were able to explain, we feel we need to deeper analyze. In addition, we will try to separate the different types of shadow economy and distinguish further whether any of them can be influenced more. Furthermore, we plan to look at countries outside the EU. Our findings can assist policymakers in using the capital markets as well as the various pillars of the economy as levers to reduce the undeclared economy of their countries.

\section{References}

Anoop, S., Sonali, J., \& Adil, M. (2012). Inclusive Growth, Institutions, and the Underground Economy. IMF Working Paper WP/12/47. International Monetary Fund.

Arellano, M., \& Bond, S. (1991). Some tests of specification for panel data: Monte Carlo evidence and an application to employment equations. Review of Economics and Statistics, 58, 277-297. https://doi.org/10.2307/2297968

Arellano, M., \& Bond, S. (1988). Dynamic panel data estimation using PPD: a guide for users. London: Institute for Fiscal Studies.

Baltagi, B. H., \& Li, D. (2002). Series estimation of partially linear panel data models with fixed effects. Annals of Economics and Finance, 3(1), 103-116.

Beloded, O. (2005). Shadow Economy of Ukraine: The Case of Financial Constraints. Master Thesis, National University "Kyiv-Mohyla Academy".

Berdiev, A. N., \& Saunoris, J. W. (2016). Financial development and the shadow economy: A panel VAR analysis. Economic Modelling, 57, 197-207. https://doi.org/10.1016/j.econmod.2016.03.028

Bittencourt, M., Gupta, R., \& Stander, L. (2014). Tax Evasion, Financial Development and Inflation: Theory and Empirical Evidence. Journal of Banking \& Finance, 41, 194-208. https://doi.org/10.1016/j.jbankfin.2014.01.009

Blackburn, K., Bose, N., \& Capasso, S. (2012). Tax Evasion, the Underground Economy and Financial Development. Journal of Economic Behavior \& Organization, 83(2), 243-253. https://doi.org/10.1016/j.jebo.2012.05.019

Blundell, R., \& Bond, S. (1998). Initial conditions and moment restrictions in dynamic panel data models. Journal of Econometrics, 87(1), 115-143. https://doi.org/10.1016/S0304-4076(98)00009-8

Bond, S. R., Hoeffler, A., \& Temple, J. R. (2001). GMM estimation of empirical growth models.

Bose, N., Capasso, S., \& Andreas Wurm, M. (2012). The impact of banking development on the size of shadow economies. Journal of Economic Studies, 39(6), 620-638. https://doi.org/10.1108/01443581211274584

Capasso, S., \& Jappelli, T. (2013). Financial Development and the Underground Economy. Journal of Development Economics, 101, 167-178. https://doi.org/10.1016/j.jdeveco.2012.10.005

Din, B. H. (2016). Estimating the Determinants of Shadow Economy in Malaysia. GEOGRAFIA Online Malaysian Journal of Society and Space, 12(5), 191-201.

Fetai, B. T. (2018). Does financial development accelerate economic growth?. Journal of Financial Economic Policy. https://doi.org/10.1108/JFEP-11-2017-0118 
Greene, W. H. (2003). Econometric analysis. Pearson Education India.

Hajilee, M., Stringer, D. Y., \& Metghalchi, M. (2017). Financial market inclusion, shadow economy and economic growth: New evidence from emerging economies. The Quarterly Review of Economics and Finance, 66, 149-158.

Habibullah, M. S., Din, B. H., Yusof-Saari, M., \& Baharom, A. H. (2016). Shadow Economy and Financial Sector Development in Malaysia. International Journal of Economics and Financial Issues, 6(S7), 181-185.

Kao, C., \& Chiang, M. H. (2000). On the estimation and inference of a cointegrated regression in panel data. Advances in Econometrics, 15, 179-222. https://doi.org/10.1016/S0731-9053(00)15007-8

Kelmanson, B., Kirabaeva, K., Medina, L, Mircheva, B., \& Weiss, J. (2019). Explaining the shadow economy in Europe: size, causes and policy options. IMF Working Paper, WP/19/278: 1-29. https://doi.org/10.5089/9781513520698.001

Maddala, G. S., \& Wu, S. (1999). A Comparative Study of Unit Root Tests With Panel. https://doi.org/10.1111/1468-0084.61.s1.13

Medina, L., \& Schneider, F. (2018). Shadow Economies Around the World: What Did We Learn Over the Last 20 Years?. IMF Working Paper, WP/18/17. https://doi.org/10.5089/9781484338636.001

Pedroni, P. (1999). Critical values for cointegration tests in heterogeneous panels with multiple regressors. Oxford Bulletin of Economics and Statistics, 61(S1), 653-670. https://doi.org/10.1111/1468-0084.61.s1.14

Pesaran, M. H. (2015). Time Series and Panel Data Econometrics. Oxford University Press. https://doi.org/10.1093/acprof:oso/9780198736912.001.0001

Pesaran, M. H. (2004). General Diagnostic Tests for Cross Section Dependence in Panels. Cambridge Working Papers in Economics 0435. Faculty of Economics (DAE), University of Cambridge.

Pesaran, M. H. (2003). A Simple Panel Unit Root Test in the Presence of Cross Section Dependence. Cambridge Working Papers in Economics 0346, Faculty of Economics (DAE), University of Cambridge. https://doi.org/10.2139/ssrn.457280

Park, N-W. (2005). Underground Economy: Causes and Size, Korean Institute of Public Finance. World Bank $\begin{array}{lllll}\text { Presentation. } & \text { Retrieved } & \text { Januray } & \text { 2020, from }\end{array}$ http://siteresources.worldbank.org/PSGLP/Resources/UndergroundEconomyPark.pdf

Schneider, F., \& Enste, D. H. (2000). Shadow Economies: Size, Causes, and Consequences. Journal of Economic Literature, 38(1), 77-114. https://doi.org/10.1257/jel.38.1.77

Schneider, F. (2007). Shadow Economies and Corruption All Over the World: New Estimates for 145 Countries. Economics: The Open-Access, Open-Assessment $\quad$ E-Journal, 1. https://doi.org/10.5018/economics-ejournal.ja.2007-9

Singh, A., Jain-Chandra, S., \& Mohommad, A. (2012a). Inclusive Growth, Institutions, and the Underground Economy. IMF Working Paper, WP/12/47. https://doi.org/10.5089/9781463937089.001

Singh, A., Jain-Chandra, S., \& Mohommad, A. (2012b). Out of the Shadows, Finance \& Development. IMF, 49(2), $42-45$.

The World Bank. (2018). World Development Indicators. Retrieved September 1, 2018, from https://data.worldbank.org/products/wdi

Verbeek, M. (2008). A guide to modern econometrics. John Wiley \& Sons.

Woolridge, J. M. (2009). Introductory Econometrics: A Modern Approach (5th ed.). South-Western, Michigan State University, 378, p. 57.

\section{Copyrights}

Copyright for this article is retained by the author(s), with first publication rights granted to the journal.

This is an open-access article distributed under the terms and conditions of the Creative Commons Attribution license (http://creativecommons.org/licenses/by/4.0/). 